\title{
Controle social expresso em representações sociais de violência, insegurança e medo
}

MARGARTAA ROSA GAYRIA M.

\section{Resumo}

Neste ensaio analisamos as representações de violência e sentimentos derivados - insegurança e medo para duas gerações de pessoas (jovens e adultos) moradoras de municípios do Rio Grande do Sul, caracterizados pelo alto índice de criminalidade. Mostramos como a análise das representações sociais, elaborada com base nos discursos sobre o tema, permite apreender ações, sentimentos, valores e idéias criadas pelas pessoas, como estratégias de controle social e prevenção da violência. Assinalamos também diferenças entre as gerações nas concepções de violência e em ações desenvolvidas para enfrentar o problema. No entanto, mostramos como, independentemente da posição social que a pessoa ocupa, os elementos dos discursos em torno da violência constroem-se em decorrência de experiências sociais vivenciadas em ambientes vulneráveis à violência. Este fenômeno é acentuado em contextos sociais nos quais emana a crise das instituições, em que a família, a igreja e a polícia perdem o poder de exercer o controle social e tornam-se, portanto, ineficazes no cumprimento desta função, induzindo as pessoas a desenvolverem, individualmente, mecanismos de controle da situação ${ }^{1}$.

Palavras-chave: Violência. Controle social. Representação social. M edo. Insegurança.

Nota: este artigo sofreu alterações por solicitação do editor em 2011, conforme ERRATA publicada no Volume 13 Número 27 do periódico.

\footnotetext{
* Doutora pela UFRRJ e Profa de Sociologia da Universidade Federal do Rio Grande do Sul, vinculada ao Grupo de Pesquisa Violência e Cidadania do PPGS - UFRGS.

1 A autora agradece a contribuição de Anapaula Rasera para a elaboração do presente artigo, bem como 0 acesso aos dados coletados por esta no município de Alvorada(RS), no desenvolvimento de sua dissertação de mestrado.
} 


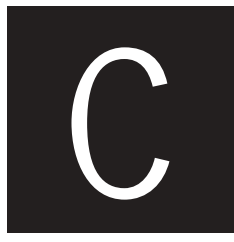

ientes da relevância analítica que tem o exame da familiaridade com que pessoas de diversas categorias sociais manifestam-se acerca da violência ao se pronunciarem através de opiniões correntes, empreendemos a tarefa de discorrer sobre o tema. Propomo-nos a aprofundar no conteúdo dos discursos que tematizam a violência, ultrapassando as visões do senso comum. Postura sustentada no pressuposto de que são diversas as concepções de violência, elas variam de acordo com o contexto histórico, social e cultural onde se situa o problema. E no reconhecimento de que "a realidade cotidiana da violência difere das representações feitas so bre ela e dos discursos ideológicos ou míticos construídos em torno dela". (MICHAUD, 1982).

Com base na perspectiva teórico-metodológica referida acima², apresentamos, na seqüência deste ensaio, as representações de violência e sentimentos derivados - insegurança e medo - para pessoas de duas faixas etárias (jovense adultos) moradores de Alvorada e São Leopoldo, municípios do Rio Grande do Sul, destacadospelo alto índice de criminalidade. Representações através das quais apreendemos estratégias de controle social e prevenção da violência, desenvolvidas na experiência cotidiana das pessoas.

\section{Representações Sociais}

O ptamos pela análise das representações sociais, por possibilitar uma aproximação à fenomenologia da violência fundamentada no que as pessoas pensam, como agem em situações de violência e os sentimentos e emoções que nelas produz. A inclusão de sentimentos e emoções no material analítico obedece a que estes conferem à representação coletiva um status

2 A violência pode ser abordada do ponto de vista etiológico ou etimológico, de uma abordagem micro ou macrossociológica, baseado em ferramentas antropológicas, sociológicas e filosóficas, e assim por diante. 
epistemológico particular, uma vez que agregam à cognição a não racionalidade (O LIVEIRA, 1991).

Indagar pelas representações sociais é indagar por idéias e sentimentos às que o indivíduo dá voz através da fala e das ações. Q uer dizer, a análise das representações sociais de violência e sentimentos derivados permite desvendar subjetividades, idéias, práticas e atitudes dos atores sociais em torno da violência, e estratégias individuais e coletivas utilizadas para enfrentá-la.

Paralelamente à análise dos discursos sobre violência, examinamos a insegurança e o medo como sentimentos e emoções decorrentes da experiência de vida em ambientes sociais dominad os pela violência, em vista de que estes fazem parte da estrutura de ação e de pensamento. Dados obtidos do relato de acontecimentos violentos e de discursos em torno da violência, feitos em entrevistas dirigidas com grupos de duas faixas etárias (jovens e adultos) (RASERA, 2008). ${ }^{3}$

Da perspectiva adotada aqui, a violência, a segurança e o medo não designam objetos e práticas empiricamente observáveis, mas representações sociais. O s significados destas categorias (violência, segurança e medo) evocam um tipo de relação com o fenômeno. Representam formas de expressão de um mundo social, as quais interferem na prática social dosatores. 0 interesse em aprofundar nelas, nesses universos sociais, surgiu ao perceber que violência, insegurança e medo são categorias acionadas para nomear e qualificar ações, concepções, sentimentos e emoções decorrentes do convívio em um ambiente com alto índice de criminalidade. Q uer dizer, procuramos transformar essas categorias do senso comum em categorias sociológicas (RASERA, 2008).

Esta postura teórica e metodológica inspira-se no argumento de Bourdieu (2004), segundo o qual, para apreender um fato social, no caso, a

\footnotetext{
3 Em Alvorada, foram entrevistados 17 jovens (entre 15 e 17 anos) e 22 adultose idosos (idades entre 50 e 70 anos) participantes de programas de assistência social da Prefeitura. Em São Leopoldo, as informações foram colhidas em conversas dirigidas com pessoas de diversas categorias sociais, participantes de programas do município, que visam prevenir e combater a violência.
} 
fenomenologia da violência, é preciso saber o que a pessoa que age pensa a seu respeito e os sentimentos que gera. Em suma, o conceito de representações sociais permite compreender fatos sociais a partir das relações que os sujeitos estabelecem com o mundo social no qual se inserem, da maneira como eles interiorizam experiências sociais e das interpretações que os próp rios sujeitos fazem das mesmas. Fundamentamo-nos, portanto, no pressuposto de que as narrativas têm um caráter simbólico que ultrapassa o episódico das experiências vividas, pois as experiências individuais estão imbricadas em experiências sociais.

0 exame das representações sociais sobre o assunto nós o realizamos em grupos vulneráveis à violência, nos municípios de Alvorada e de São Leopoldo. São, como foi informado antes, pessoas de duas gerações: jovens e adultos participantes de projetos de assistência social das Prefeituras M unicipais, que visam enfrentar problemas específicos aos grupos. O s jovens provêm de ambientes de alta vulnerabilidade à violência. E no caso dos adultos, à vulnerabilidade do ambiente em que habitam soma-se a vulnerabilidade pela idade.

\section{Significados da violência para adultos}

Ao nos debruçarmos sobre as representações sociais produzidas pela categoria social de adultos ${ }^{4}$ acerca da violência, deparamos-nos com o fato de que o conteúdo dos discursos difere quando estes aludem a uma concepção geral da violência, isto é, ao serem instigados a definir a violência em abstrato ${ }^{5}$; das narrativas em que a questão colocada refere-se direta-

\footnotetext{
4 Trata-se de uma idéia de geração que, seguindo Debert (1999), não é marcada pela idade das pessoas que a compartilham senão pela vivência de eventos que marcam trajetórias passadas e futuras.

5 A pergunta realizada foi: "O que é a violência para você?"
} 
mente à violência na cidade onde moram, quando respondem se a violência é um fato imanente a seu município. Em outros termos, percebemos diferenças no mapa das representações sociais da violência, nas situações em que o fenômeno é pensado em relação a um contexto histórico e social específico, daquelas em que é abordado de maneira descontextualizada.

Esse reconhecimento da existência de diferenças substanciais nas representações sociais de violência levou-nos a desenvolver os conceitos de: "desterritorialização da violência" e "violência no território dos outros", como instrumentos de interpretação, assunto sobre o qual tratamos a seguir, mas, antes, queremos chamar a atenção para uma observação geral a respeito das diferenças assinaladas antes: em circunstâncias nas quais os adultos são estimulados a definir a violência, as asserções são muito mais amplas do que nos discursos nos quais respondem se o contexto espacial e temporal em que se inserem é violento. Pretendemos, então, que os conceitos mencionados tragam luzes para a compreensão desta questão e de outras levantadas no decorrer deste ensaio.

\section{Desterritorialização da violência}

O conceito "desterritorialização da violência" surgiu da percepção de que, para a maior parte dos adultos, a situação do município onde mora, em relação à violência, "é como todo lugar". As falas aludem à violência como um fato que extrapola as fronteiras do município, não está apenas adstrita ao "aqui". Idéia reforçada ao afirmar que é através dos noticiários da TV que tomam conhecimento de alguns acontecimentos violentos. As informações referem-se a casos de violência ocorridos em diversas localidades do Estado e do País. Não fazem menção aos meios de comunicação de âmbito local como as rádios locais, que subministram informações sobre violência nos respectivos municípios e, se o fizessem, a conotação das informações seria outra. 
Ao tratar da violência, os adultos remetem-se a outros espaços, diferentes do próprio, não só físicos, mas de tempo. Para pessoas desta geração, o passado serve de parâmetro de comparação com as vivências ligadas à violência na atualidade. Q uer dizer, nos relatos, contrastam o cenário atual com a violência ligada a fatos do passado, mapeando, através da fala, representações dos espaços sociais onde foram construídas experiências anteriores em relação à violência. Afirmam que, se no passado era um fenômeno passível de delimitar em termos numéricose espaciais no cotidiano das pessoas, hoje, conhecer cada caso de violência é impossível, pois esta se expande espacialmente e em quantidade. Não só acontece simultaneamente em diversos lugares, como são inúmeros os casos. Consideram a violência um fenômeno incalculável, imensurável e de grande magnitude. 0 que indicam as colocações dos adultos é que, para eles, a dimensão do problema é tão ampla que os impede de controlá-la e optam por encará-la como questão latente e volátil enquanto tal, não expressam consciência de sua interferência na vida cotidiana.

U ma leitura das colocações dos adultos em relação à violência, apoiada nos pressupostos teóricos de Berman (1986), indica que, por esta ótica, a violência é vivenciada como uma experiência de modernidade que anula as fronteiras e une a espécie humana. Porém é uma unidade paradoxal, uma unidade que despoja as pessoas num turbilhão de luta e contradição. N uma ambiência de insegurança, que a Polícia mal controla, por causa da acumulação demográfica, a favelização e o desemprego (DELM EAU, 2006).

Em suas asseverações so bre violência, os adultos frisam que ela não é uma característica específica dos municípios em que moram, mas de qualquer cidade em crescimento. Fato que interpretamos, inspirados ainda em Berman (1986), como expressão da consciência social de que a violência é a marca de espaços que vivenciam um processo amplo de modernização. $\mathrm{E}$ ser moderno é encontrar-se num ambiente que promete crescimento e 
transformação, entre outras coisas, mas, ao mesmo tempo, ameaça destruir tudo o que somos e o que temos.

$N$ as narrativas elaboradas para responder diretamente se a violência é um elemento característico do município em que moram, os adultos evitaram balizar o estigma desse município de violento, como é apresentado pela opinião pública. Consideramos hipoteticamente que a negação da violência, enquanto característica própria do ambiente em que se desenvolvem as pessoas, é uma forma de manifestar a identidade com o espaço, que não é apenas lugar de moradia, senão também espaço de referência social e cultural. Em vista de que, como demonstram as teorias de identidade social, no processo de construção das identidades sociais entram em jogo não só os papéis e as posições de cada pessoa em sociedade, senão também a imbricação dos atores sociais com o espaço ao qual estão ligados. Assim, a negação da violência no espaço é uma forma de manifestar uma relação de alteridade com o fenômeno. Argumentamos, ainda, que, um elemento que incide nessa identificação com o espaço é o sentimento de afeto construído pelo município ao longo dosanos, pois todos os entrevistados desta geração, em São Leopoldo e em Alvorada, sem exceção, migraram de outros municípios do Estado há mais de 20 anos e declararam gostar muito do lugar em que moram.

No caso de Alvorada, a negação da violência como categoria usada para qualificar o município, reforça a alusão aos dados fornecidos pelo Prefeito numa palestra em dezembro de 2007, à qual compareceram alguns adultos com quem conversamos. Na palestra, o Prefeito apresenta uma queda no índice de violência, informa que, se antes ocupava o primeiro lugar no Estado, atualmente ocupa o quinto. Tivemos conhecimento de que, nesse município, há uma campanha que começou na Administração municipal anterior, destinada a eliminar o estigma de Alvorada como cidade violenta. U ma das ações consistiu em difundir um novo apelido para a cidade: "capital da solidariedade". 
Se analisarmos, à luz da literatura, a nova qualificação de Alvorada como "capital da solidariedade" para contrapor o estigma de cidade violenta, observamos que a esta contraposição subjaz a consciência da vulnerabilidade à violência a que estão expostas as pessoas em contextos sociais em que a oposição entre interesses individuais e coletivos é acentuada. Conjuntura esta que se dá em circunstâncias nas quais se negam as diferenças sociais e, para adquirir bens próprios, apropria-se do outro, isto é, quando o princípio de solidariedade está ausente das relações sociais (RASERA, 2008).

Como disse Birman (2005), refletindo acerca do que ele chama de "mal-estar na atualidade", a exaltação da individualidade na sociedade implica a volatilização da solidariedade, sua perda de valor. Vive-se com o ethos de "cada um por si". O sujeito encara o outro apenas como objeto de usufruto. N este cenário, as relações entre as pessoas assumem características agonísticas, cenário propício para a explosão da violência. "A eliminação do outro se este resiste o faz obstáculo ao gozo do sujeito, nos dias atuais se impõe como uma banalidade" (BIRM AN, 2005 apud RASERA, 2008).

\section{Violência no território dos outros}

"Violência no território dos outros" é outro conceito construído para refletir acerca das concepções de violência para os adultos como fato social distante. Surgiu ao perceber que, as pessoas nesta faixa etária eventualmente reconhecem que existe violência no município, e isto observamos nos discursos em que a vinculam a um espaço social ou a um espaço físico, ou a um espaço de tempo diferente do próprio. Afirmam que há violência: "mais para lá para os fundos, para baixo, em alguns bairros". Ao caracterizar a violência no município, nomeiam espaços físicos distantes daquele ao qual pertencem. Bem como designam espaços sociais construídos em torno de práticas de violência com os quais eles não se identificam. 
Advertem que aos territórios de violência pertence apenas quem se identifica com as práticas e valores que a sustentam. Da violência participa só quem quer, é uma opção individual. U ma outra posição assumida por adultos para se colocarem distantes dos territórios de violência é a afirmação de que nem na condição de vítimas se envolvem com a fenomenologia da violência. Para elucidar essa postura, evocam situações de risco vivenciadas por eles nas que não são atingidas. M anifestam-se distantes da criminalidade ao não sentirem a possibilidade de vitimização, demonstrando, nestas situações, não se sentirem vítimas do temor produzido por uma realidade objetiva (ECKERT, 2002).

Nos casos em que os adultos aludem a algum tipo de envolvimento com a violência, mencionam acontecimentos vivenciados, ou não, por eles, correspondentes a outro espaço de tempo. Remetem-se a um passado longínquo, a outras fases do ciclo de vida: durante a criação dos filhos ou quando estavam na fase de vida produtiva, entre outras. Q uer dizer, mesmo quem reconhece a expressão da violência no município em que mora, a apresenta, como foi assinalado antes, enquanto fato distante no espaço e no tempo, longe da experiência de vida cotidiana na atualidade. Distanciamento que corresponde a um sentimento de alienação em relação ao fenômeno, desenvolvido como mecanismo de defesa psicológica dessas pessoas pela impossibilidade de agir na resolução do problema, e a "tendência ao esquecimento" encarregada de manter a tranqüilidade e a ordem psíquica (NIETZSCHE, 2007; p. 56).

\section{Representações de violência dos jovens}

Se, como foi anotado antes, os adultos geralmente concebem a violência como um fenômeno desterritorializado ou adstrito ao território de outros, na visão dos jovens, a violência é um fenômeno inerente ao muni- 
cípio ao qual pertencem. A maioria dos jovens narrou acontecimentos de violência recentes, próximos no tempo, no espaço físico e nas relações sociais. São vizinhos, familiares e amigos, vítimas.

Entre os fatos que os jovens destacam é a enorme quantidade de mortes violentas, a diversidade de situações de risco que ali eles enfrentam por causa dos tiroteios, de assaltos, do poder dos marginais, sustentado em práticas de violência, e da imprevisibilidade dessas práticas que impedem a proteção aos moradores. Isto é, eles evocam o risco imanente em suas rotinas, a ameaça à so brevivência física pela criminalidade desmesurada em que se manifesta o crime organizado.

Para os jovens, a morte violenta é um fenômeno com o qual convivem permanentemente. Portanto, é a manifestação de violência mais evocada por esses atores sociais. $\mathrm{Na}$ alu são a este crime, feita na condição de pessoas temerosas da vitimização, são três as razões principais que o provocam: 1) a justiça comunitária, ou seja, em termos coloquiais: o "ajuste de contas" com quem "fez coisa ruim"; 2) os assaltos, pois, em diversas ocasiões, desencadeiam mortes; 3) as brigas, seja entre familiares, vizinhas, amigos ou desconhecidos, freqüentemente terminam com vítimas mortais.

Mesmo delineando um panorama violento no município, os jovens assumem uma postura destinada a soterrar ou desvirtuar as informações oferecidas à população sobre a violência no município, ponderando que há violência no município, mas não tanto quanto é apresentada pela mídia e apontam outros lugares onde consideram pior a situação ${ }^{6}$.

Contudo, na expressão simbólica de viver numa cidade violenta, os jovens remetem-se a representações cobertas por um discurso de poder, que apresenta a gravidade da violência e da criminalidade, divulgados pela mídia. Como bem disse Tavares (2002), na disseminação das representa-

6 Para sustentar este argumento, informam que Porto Alegre tem vilas onde há que pagar pedágio para entrar. 
ções sociais de violência, contribuem os meios de comunicação de massa, estes dramatizam a violência e difundem a espectacularização do crime violento. Grande parte dos sentimentos e emoções expressos em falas e opiniões sobre violência fundamenta-se no que os meios de comunicação de massa transmitem ${ }^{7}$. A produção dessas representações é um efeito da violência simbólica exercida pelo campo jornalístico.

Circunscrevendo nossas reflexões às representações sociais do fenômeno no universo empírico estudado, de um modo geral, notamos que, apesar das diferenças entre as gerações em práticas e idéias relativas à violência, em circunstâncias nas quais a violência é concebida em abstrato, de maneira descontextualizada, as diferenças de posição entre jovens e adultos não se manifestam nitidamente.

Deste modo, o conteúdo semântico da categoria "violência" no âmbito dos jovens alude ao consumo de drogase álcool: "violência é droga, é maconha, é bebida", mesmo que depois, através das conversas, refiram-se a outras manifestações: brigas, surras, assaltos, estupro, morte. Por sua vez, os adultos, nas definições de violência, apontam para a droga e a bebida, mas com um discurso elaborado sobre o assunto, no sentido de que as classificam segundo a forma em que acontece e os atores envolvidos. M encionam a violência física, a do corpo, do dia-dia e entre gangues. Além de eles conceberem a ausência de proteção social dos cidadãos pelo Estado, um fenômeno de violência do qual a população é vítima, destacando a falta de assistência à criança e ao idoso, e o desemprego.

O bservamos nas narrativas de violência produzidas por ambas as gerações, relação entre violência e ausência de proteção social. Na análise dos

\footnotetext{
7 As "verdades" acerca de fatos violentos são produzidas pelos meios de comunicação, estes informam de acordo com interesses do setor que representam e fazem com que a violência passe a fazer parte do dia-a-dia, mesmo de quem nunca a confrontou diretamente enquanto experiência de um processo vivido. O sproprietários dos meios de comunicação lucram com as imagens, eles exploram o prazer das pessoas em olhar para a dor dos outros. A violência torna-se um objeto de consumo, um produto com amplo poder de venda no mercado de informação. (Sontag, 2003; Bourdieu, 1997).
} 
discursos, percebemos que, do ponto de vista dos informantes, a vulnerabilidade à violência é acrescida por causa das dificuldades que as pessoas enfrentam para atingir o direito cidadão à segurança e à liberdade. Direitos considerados precários, pois os cidadãos carecem de uma série de elementos necessários que garantam a proteção social e, na resolução do problema, não há projetos de participação conjunta dos setores públicos e os privados.

Enfim, de um modo geral, nas designações de violência de jovens e adultos perpassa o reconhecimento da existência de certas conjunturas sociais favoráveis à produção de violência. N este sentido, associam-se as práticas de violência a situações de vulnerabilidade social. Em suma: os significados de violência incluem não só idéias e práticas definidoras do fenômeno, mas também as condições sociais e individuais que permitem o desenvolvimento destas práticas e a reprodução dos valores que lhes dão sustento.

A vulnerabilidade diz respeito tanto à condição individual quanto à social. Entre os fatores individuais determinantes para que as pessoas incorram em atos violentos, sobressai o caráter moral do indivíduo, a desmoralização imanente à conduta individual. D este modo, na avaliação situacional do jovem imiscuído em violência, baseada em preceitos morais, subjaz a exposição de um comportamento desviante, sedimentado em resposta à posição e à situação do indivíduo em sociedade. Trata-se de adolescentes, jovens, sem dinheiro, sem ocupação, que, na visão dos adultos: "só pensam bobagem". Postulam que a falta de emprego em alguns casos induz as pessoas a entrarem no narcotráfico.

Em reiteradas ocasiões, assinalam que um dos elementos individuais que contribuem para o desenvolvimento do comportamento violento é o envolvimento com o tráfico de drogas, no âmbito do qual, a violência é um instrumento de poder. 0 corre, por exemplo, nos casos em que o adolescente assume o papel de "chefe" e como tal pretende exercer -ou exerce - domínio sobre outros. Estas observações lembram a leitura que Zaluar 
(2004) faz da sociabilidade dos jovensnas favelas cariocas. M uitos se tornam membros de quadrilha, seja para pagarem dívidas, seja para se sentirem mais fortes diante de seus inimigos, seja para intimidarem vítimas e para se imporem aos policiais, afundando cada vez mais no círculo que entendem ser praticamente interminável. Com seus patrões aprendem a se comportar de maneira violenta, portando armas de fogo e praticando assaltos.

O utro dosmotivosindividuais apontadosque predispõem a protagonizar atos violentos é o consumo de álcool e drogas. 0 excesso no consumo desses produtos provoca a perda de consciência, estado no qual o indivíduo fica mais propenso a se envolver em crimes e brigas. O u seja, o consumo de droga e bebida potencializa a violência. Assim, um jovem, por exemplo, sob efeitos de entorpecentes, tem uma forte tendência a cometer atos violentos. Segundo este raciocínio e à luz de Hobbes (1999), o jovem bêbado ou drogado passa a agir por instinto e agride com mais facilidade. Paralelamente ao anterior, uma das conseqüências do uso de drogas por parte dos jovens de subúrbios, é, como assinala Zaluar (2004), que os jovens começam como usuários de drogas e posteriormente são levados a roubar, assaltar e às vezes até matar para pagar aqueles que os ameaçam de matar se não saldam a dívida.

Acerca das peculiaridades sociais dos ambientes em que se desenvolvem os jovens, cabe salientar que, no contexto dos setores marginais das cidades, os jovens representam o setor social mais vulnerável às transformações ocorridas na atividade econômica neoliberal e no modo de vida. Novaes e Vannuchi (2004), pensando em nível mundial, afirmam que, "os jovens são os alvos de mudanças sociais em curso. Eles são os mais atingidos pela retração do mercado, pela terciarização e flexibilização das relações de trabalho" (p.8) (RASERA, 2008).

Soma-se ao anterior a carência de políticas públicas dirigidas à juventude e a falta de reconhecimento social como estimuladores, na geração 
dos jovens, do desencanto, da descrença na legitimidade das instituições, da incerteza em relação ao futuro. Por este viés, "o futuro é o signo da incerteza, da instabilidade, da insegurança, ante a qual toda obra de autoconstrução moral vacila. (...) A promessa de mudança ultrapassa o horizonte positivo das utopias e da esperança, na medida em que ameaça com o desconhecido" (SO ARES, 1996; p. 60).

As deficiências na estrutura econômica e social apontadas como favorecedoras das condições para a produção da violência, refletem-se na estrutura familiar, no desemprego, na escassez de policiamento, no crescimento do tráfico de drogas, na formação de gangues e na socialização em ambientesocupados por jovens viciados em drogas. N este panorama, a escola e a família perdem a referência que tiveram para gerações precedentes.

No que diz respeito especificamente às falhas na estrutura familiar, consideram que estas ocorrem pelo descaso dos pais nas relações com os filhos: não participam das atividades dos filhos nem Ihes colocam limites, pois os deixam livres, soltos; não os protegem em situações de risco, como andar desacompanhado pelas ruas, evitando que seus descendentes se desviem do caminho que conduz à escola e enveredem pela violência. Para os adultos, não só é indispensável o acompanhamento dos pais no deslocamento dos filhos da casa à escola, mas também na formação moral. Como forma de prevenção da violência, os pais devem fornecer uma educação moral aos jovens, através da qual estes últimos aprendam a distinguir o bom do ruim, o certo do errado, isto é, um padrão de valores que oriente o comportamento social e cultural.

Porém, a mobilização social dos jovens em busca de recursos monetários costuma implicar na ruptura com um processo de socialização em família. E, através dessa ruptura, a possibilidade de se engajarem em outras formas de sociabilidade. Nos novos espaços sociais por onde passam a transitar, os jovens constroem visões de mundo e redes de sociabilidade 
decisivas na escolha de futuros caminhos. Nota-se aqui, ao igual do que foi asseverado em outros estudos sobre jovens que, à falta de oportunidades de trabalho e de alternativas de lazer, soma-se a vulnerabilidade à violência a que estão expostos estes atores sociais, e isso se reflete em inúmeras mortes.

U m balanço da situação contemporânea dos jovens revela que, enquanto a falta de alternativas de trabalho e lazer não é traço novo na vida dos jovens de baixa renda no Brasil, o medo, o envolvimento ativo ou passivo em atos violentos e no tráfico de drogas são as marcas de uma geração que está sendo dizimada, independentemente da camada social à qual pertencem. Não são apenas os jovens de setores pobres os envolvidos em violência, hipótese que rompe a associação entre miséria e violência. No entanto, 0 abandono e a falta de perspectivas favorecem as dinâmicas perversas de recrutamento de meninos pobres, pelo narcotráfico. A situação faz com que os moradores das periferias manifestem seu descontentamento como vítimas do processo de exclusão social e a vontade de serem reconhecidose valorizados como cidadãos (CASTRO e ABRAM OVAY, 2002).

Cabe sublinhar ainda, no esboço das peculiaridades sociais do ambiente em que se desenvolvem os jovens, que estes estão imersos num mundo social marcado pelo esvaziamento de fronteiras culturais entre camadas sociais. Independentemente da origem social, os jovens recebem, através da mídia, a mesma qualidade de informações acerca de produtos e serviços oferecidos pelo mercado. Estejam adstritos a espaços periféricos ou centrais das localidades, desenvolvem gostos homogêneos, querem o mesmo tipo de bens de consumo. Contudo, as fronteiras econômicas são acirradas. Apesar de os desejos serem de igual natureza, as possibilidades de obter bens diferem enormemente entre uma camada social e outra. Isso leva a que os jovens pertencentes a famílias de escassos recursos econômicos vejam seus desejos frustrados. N esta ordem de idéias, "a frustração remete mais ao indivíduo preocupado em consumir do que ao sujeito esforçandose para construir-se" (WIEVIO RKA; 2006 p. 204). 
A raiz da frustração, o jovem, enquanto sujeito que tem a capacidade de construir-se a si próprio, de escolher, de produzir sua existência ${ }^{8}$, recorre a estratégias diversas para ter acesso ao consumo de bens desejados, que podem desencadear no crime. É, por exemplo, a situação bastante conhecida do jovem que, como "sujeito contrariado, interditado, impossível ou infeliz" (WIEVIO RKA, 2006; p. 203) comete crimes. Rouba, furta e/ou assassina para comprar droga ou para adquirir produtos da sociedade de consumo dosquais está privado pela escassez de recursos monetários de que dispõe. Pois, tal como assinala Wieviorka (2006), o sujeito encontra na ação sua realização concreta mais importante, mesmo sendo destrutiva ou violenta. A violência é, portanto, o recurso utilizado para estar a par das demandas culturais de uma sociedade que dá preeminência aos valores materiais, mas também é a forma de obter o reconhecimento simbólico de sua identidade social (RASERA, 2008).

Tal como temos assinalado até agora, jovens e adultos, através de suas concepções de violência aludem a um leque de manifestações e motivações do fenômeno nos municípios selecionados ${ }^{9}$, demonstrando, neste sentido, sua complexidade. E, cientes de que, em nossa proposta de mergulhar no problema, corramos o risco da dispersão em torno de uma série de fatos, e ficarmos impedidos de delimitar e aprofundar o objeto que pretendemos apreender, optamos por centrar a atenção em apenas uma das manifestações de violência, percebida pelos discursos como a mais expressiva: o homicídio.

\section{Homicídio}

Por estarem perante ambientes sociais nos quais a morte violenta é um fenômeno banal, o homicídio é bastante evocado pelas pessoas nas

8 Concepção de sujeito de W ieviorka (2006).

90 s discursos que evocam formas de expressão de violência são comuns a ambas faixas etárias, ainda que os roubos na rua e crimes contra o patrimônio sejam apenas mencionados por adultose idosos. 
narrativas referentes à violência. A expressividade anunciada nas representações sociais co incide com fontes oficiais. No município de Alvorada, de acordo com osdados do Plano de Segurança Pública de Alvorada (ALVIM , 2004), e em São Leopoldo ${ }^{10}$, o homicídio é um delito que apresenta certa regularidade.

U ma questão que permeia os discursos relativos ao assassinato é a associação deste crime com a droga, fundamentado em vários fatores. Um delesé que as drogas potencializam os assassinatos. As pessoas sob o efeito da droga e do álcool têm predisposição para matar. E da mesma forma que, sob o efeito da droga o jovem é violento e assassino, a falta da droga gera uma atitude violenta. As pessoas viciadas se exasperam quando Ihes falta a droga, e nesse estado, podem acabar cometendo homicídios. De acordo com o anterior, o jovem dependente da droga, quando a consome ou quando sente necessidade de consumi-la, tem bastante tendência a praticar homicídios.

Por outra parte, pessoas de ambas gerações (jovens e adultos) coincidem em que o homicídio, muitas vezes, é decorrente do tráfico de drogas, isto é, de desavenças e brigas na comercialização do produto. Assassinam o membro do grupo que "cai fora" e o consumidor que não paga. Neste sentido, o assassinato é uma prática utilizada para condenar quem infringe a lei do tráfico. Sendo que, a bravura contida nas brigas provoca, em diversas situações, a morte de pessoas que não tinham nada a ver com o negócio, vítimas de balas perdidas ou de assaltos realizados por consumidores de drogas que estão à procura de dinheiro para comprar droga ou pagar dívidas. Então, a violência que surge do tráfico e consumo de droga atinge pessoas de fora do negócio. U ma das repercussões da violência ligada ao negócio de drogas acontece no âmbito das famílias das vítimas pois em algumas ocasiões, elas entram na rede de assassinatos porque buscam fazer

10 São Leopldo, no Vale dos Sinos, está entre os dez municípios mais violentos do Estado conforme dados da Secretaria de Segurança Pública, e tem taxas recordes de assassinatos, com 63 no ano 2007, dados de IBGE. (Zero Hora, 17 de fevereiro de 2008). 
justiça matando o assassino do parente próximo, principalmente dos irmãos. Isto é, recorrem à "vingança de sangue".

É interessante observar que nem sempre o problema da droga é considerado responsabilidade do indivíduo consumidor, o comerciante, e sim um elemento de fora que penetra na sociedade e tem como conseqüência a prática de homicídios. Este posicionamento é uma forma de procurar em elementos externos a causa e a responsabilidade do crime. Em certos contextos do discurso, a droga representa um elemento de vulnerabilidade social ao qual estão expostos os jovens em sociedade. O u seja, a droga vem de fora, obedece a fraquezas da sociedade, em certa forma os jovens são vítimas desse elemento nocivo criado pela sociedade. Já o homicídio, quando não é praticado sob o efeito da droga, é totalmente vetado. N este caso, resulta de práticas de uma pessoa avaliada de mau caráter, e consideram o indivíduo responsável único pelo assassinato.

Com base nos relatos de assassinatos, percebemos que, quando a interpretação dos eventos é feita salientando elementos indicadores da crise social, da conjuntura histórica e social na qual se inscreve o sujeito (desemprego, desestruturação da família, crise das instituições, crescimento do tráfico de drogas), a conotação moral dos atos difere de quando o panorama de avaliação é a subjetividade do algoz. Assim, em alguns contextos dos discursos, o peso da responsabilidade por atos violentos não recai sobre o sujeito, mas sobre o quadro social em que ele se inscreve, no Estado e nas instituições públicas. Mas em outros, a responsabilidade é atribuída unicamente ao sujeito e, quando isso acontece, a censura social por práticas de homicídio é mais severa. A análise dessa ambivalência, à luz das teorias de W ieviorka (2006), indica, como foi apontado antes, que a censura às ações do sujeito se deve ao reconhecimento da potencialidade que ele possui de construir-se a si mesmo, de fazer opções e de produzir sua existência. Seguindo o autor, neste caso, a violência é o indício de um sujeito insatisfeito e indignado com sua própria vida. 
Além de problemas ligados às drogas, as pessoas argumentam que são várias as razões que levam a matar, incluso "até sem querer a pessoa mata", afirmam. Entre os motivos de assassinato colocam: "queima de arquivo", brigas entre gangues e paixões. Cabe salientar que, em várias ocasiões, as paixões foram colocadas como móbil de violência assassina. Elas acontecem, geralmente, quando o homem não aceita a perda da parceira (namorada, noiva, amante).

Percebemos que o homicídio é uma forma de violência que gera posições ambíguas em termos de valores morais. 0 ato de matar alguém, conforme as circunstâncias, no contexto social examinado, recebe uma valoração positiva ou negativa. A este respeito é elucidativa a fala de um entrevistado que disse: "tem gente que merece morrer e outras não fazem nada e morrem de graça". Conforme a situação, o assassinato é legítimo, é uma prática aceita no âmbito da população.

U ma abordagem geral dos critérios de definição da legalidade mostra que a qualificação de uma prática de violência ilegítima ou legítima, depende dos códigos morais utilizados na avaliação. Esses códigos são o suporte para o desenvolvimento de procedimentos legais e de recursos coercitivos utilizados para conter essas práticas. Q uer dizer, uma situação é qualificada de violenta se preenche os requisitos sociais capazes de propiciar tal reconhecimento. Atribuir a um ato o adjetivo de violento e, portanto, condenar os atores sociais responsáveis, não é um procedimento tranqüilo, livre de tensões, pelo contrário, resulta da disputa de poder entre os atores sociais que defendem posições contrárias.

A ambigüidade de posição em torno da legitimação ou deslegitimação social da violência sobressai quando o foco de análise é o assassinato, fato este que gerou o interesse em nos debruçar no assunto. Vale destacar inicialmente que, nas narrativas em torno do assassinato, há uma forte tendência a avaliar moralmente o fenômeno, avaliação sustentada em precei- 
tos religiosos. Evoca-se uma religião que induz uma moral e ameaça com sanções os contraventores. Nessa ótica, Deus representa a justiça divina, única autorizada a castigar com a morte, e Ele é considerado o ser superior que pratica a justiça, não a polícia. Só Ele tem autoridade e poder moral para eliminar a vida de uma pessoa como forma de punição. N essas representações, Deus é mais poderoso do que misericordioso e incute medo (DELMEAU, 2006).

No que diz respeito às situaçõesem que o homicídio não é reprovado, pelo contrário, aprovado, registramos as seguintes justificativas: 1) o homicídio do assassino de alguém que tem ficha na polícia por ter cometido outros assassinatos, em ocasiões nas quais, nem a família da vítima condena o crime do parente; 2) morte em defesa própria durante uma briga. Até a polícia absolve o algoz nestes casos; 3) problemas de saúde da pessoa, surgidos desde a infância, manifestos em surtos de agressividade recorrentes. É inocentada, então, a pessoa que tem um temperamento violento por natureza biológica; 4) o homicídio do protagonista do estupro de uma parente próxima, a irmã, por exemplo. Nestas circunstâncias, o assassinato também recebe 0 aval da polícia. Q uase sempre a polícia libera o algoz, argumentando que a vítima tinha ficha na polícia. Vale a pena frisar ainda que, conforme a descrição da situação, até a família do estuprador aprova seu assassinato.

Por outra parte, identificamos sanções sociais para al gumas práticas de homicídios, sustentadas em princípios morais. O bservamos as seguintes situações empíricas avaliadas negativamente em termos de valores morais, de assassinatos unanimemente reprovados: o homicídio quando a vítima é um pai de família que ao ser assassinado deixa mulher e filhos; um rapaz assassinado para roubar o tênis; o homicídio de uma senhora que sofria o mal de Alzaheimer e de uma mulher grávida. A descrição desses casos revela uma característica comum às vítimas de assassinatos: nada deviam, ou seja, não tinham praticado atos violentos que justificassem a punição com morte e/ou eram frágeis, não tinham condições físicas de se defenderem do agressor. 
Ainda refletindo sobre os preceitos morais que orientam a condena dos assassinatos, notamos que, na avaliação moral negativa, isto é, na reprovação elucidada nos discursos, os sentimentos jogam um papel fundamental. A reprovação do homicídio intensifica-se, na medida em que a exposição da vítima ao sofrimento seja mais forte. Essa ponderação foi elaborada ao perceber que, nas narrativas de assassinatos, destaca-se a crueldade contida nos atos praticados: "mataram, esquartejaram e jogaram num balão". "Jogam num formigueiro". "Matam a facadas no peito, no pescoço". "Pior é que assaltam e queimam". "Carinha drogado esfaqueou uma mulher, deu facada na barriga e no pescoço". "Pegaram uma senhora de idade aqui atrás, enforcaram e a mataram e a jogaram no mato, só porque era doente". "Em frente a minha casa mataram um jovem, deram um monte de tiro", e assim por diante. Postulamos hipoteticamente baseadosnas teorias de Foucault (1987), que em casos de vingança, o sofrimento da vítima é mesurado para reproduzir a atrocidade do crime cometido contra parente próximo. Parece-nosque, quando o assassinato é por vingança, a vítima está exposta a um sofrimento maior. Em suma, nos discursos, quase sempre aludem à agressividade, à busca da dor da vítima e à tortura. A partir das descrições de assassinatos, revela-se o sentimento de ódio imbutido nos homicídios.

A natureza da descrição de assassinatos lembra o conceito de suplício do corpo de Foucault (1987), desenvolvido para pensar as punições na época medieval. Apesar de ser outro contexto histórico, percebemos, pela análise dos dados que, no âmbito do universo empírico estudado, os atos de agressão imanentes aos assassinatos não são uma forma qualquer de punição corporal, "é uma produção diferenciada de sofrimentos, um ritual organizado para a marcação das vítimas e a manifestação do poder que pune" (Foucault, 1987; p.32). Vimos, no relato de mortes violentas, que 0 suplício é constatado por todos. Visa, portanto, à produção de sofrimento como forma de dominar pelo terror, nos casos esboçados, por parte de 
pessoas ligadas a grupos marginalizados (gangues, narcotraficantes). Q uer dizer, os excesso inerentes aos sup lícios rep resentam estratégias de poder e, paradoxalmente, sua difusão implica no controle social pelo medo.

\section{Sentimentos de medo e insegurança}

U ma das estratégias de controle social da violência é a exploração do sentimento de medo nas pessoas, sentimento aguçado ao terem conhecimento, divulgado pela mídia, do sofrimento vivenciado por vítimas de homicídios e reforçado com informações acerca da freqüência com que a violência ocorre em espaços públicos. Deste modo, o controle social e os sentimentos que o sustentam contribuem para a criação de uma "cultura do medo" (Beck, 2006; Eckert, 2002), segundo a qual, as ameaças não são mais atribuídas às forças da natureza e a Deus, como foram no período pré-moderno, senão à modernização e ao progresso. Isto é, como nota Bauman (2000), não é mais o poder cósmico que amedronta as pessoas, é o medo ao poder mundano, construído pelo homem, mas que excede a capacidade humana de resistência. 0 poder mundano transformou o medo primitivo em medo do desvio à norma. Citando Bakhtin, Bauman concebe a violência e o medo como elementos constitutivos do poder terreno. Não basta proferir normas, é necessário o terror do castigo para os que desobedecerem as normas.

$\mathrm{Na}$ medida em que a violência aumenta, as pessoas transformam-se em vítimas potenciais dos crimes contra a vida e o patrimônio, processo acompanhado do crescimento de sentimentos de medo e insegurança. No entanto, no universo pesquisado, "medo" não é a categoria usada para verbalizar sentimentos de insegurança, é um sentimento apreendido em nossa análise ao perceber a existência de mecanismos de defesa recorrentes em casos de perigo. O bservamos que, neste cenário social, os medos vêm dos homens, não de Deus e da natureza, como era antigamente, eles 
resultam de diversas situações: medo dos membros de uma família serem alvo da vingança de outros, por atos cometidos por um parente; medo da pessoa ser vítima de uma vingança individual; medo à vitimização em práticas de violência como o estupro, assalto ou homicídio. Enfim, medos diante dos quais as pessoas de ambas as gerações adotam estratégias de prevenção, privando-se de sair à noite (evitam freqüentar festas, bares e lanchonetes onde se reúnem os jovens à noite), de transitar por certos espaços e de serem precavidos nos encontros com aquele outro "perigoso", pois sabem que, nessas circunstâncias, estão mais vulneráveis à violência. Como assinala Young (2002), o aumento das taxas de criminalidade alimenta o medo público do crime e gera padrões de comportamento de evitação. Do ponto de vista desse autor, vivencia-se um fenômeno de exclusão gerado pelo crime.

Q uer dizer, os riscos que as pessoas correm estão distribuídos desigualmente, desdobram-se de maneira diferente em cada contexto. É o observado ao destacarem certos espaços públicos (bares, ruas escuras) e certos tempos sociais (noite e carnaval) como cenários de maior risco, principalmente de morte violenta (homicídios), portanto, grandes geradores de sentimentos de inseguranças e medo.

Na percepção do risco intervém, não só a falta de controle institucional de atos violentos, senão também a impossibilidade de as pessoas terem controle sobre as ações de um outro qualificado de "perigoso", por este estar marcado socialmente com "ficha na polícia", em decorrência de antecedentes criminais. Descontrole manifesto na expressão dos sentimentos, que gera esse encontro. De acordo com os discursos, são esporádicos e imprevisíveis os atos de uma pessoa que ultrapassou em suas ações o limite contra a vida de outro, levando-o à morte. $\mathrm{N}$ ão se sabe em que momento aquela pessoa que cometeu um assassinato vai atacar de novo, se vai reagir com violência à situação criada no encontro, ainda que esteja ciente de que 
nem sempre ataca, pois pode acontecer de conversar tranqüilamente. Esse quadro do imponderável os torna receosos nos encontros. 0 descontrole é maior ainda se o outro está sob efeitos da droga, pois "perde a cabeça". Em geral, ao abordar a questão nos discursos, houve mínima referência explicita à categoria medo, isto é, utilizam-se outras expressões para descrever a sensação produzida em ditos encontros: receio, falta de segurança, nervos, desastroso.

A única possibilidade de controlar as ações do outro perigoso, nos encontros, é não cortar a comunicação, não manifestar ruptura. M esmo que não estabeleçam uma relação de amizade com ela, "conversam", pois cortar a comunicação pode servir de preâmbulo às respostas violentas. Então, uma maneira de se relacionar com essa pessoa que cometeu assassinato, para se proteger, é manter um bom relacionamento. Numa conversa, um senhor disse que no local em que mora "tem gente perigosa, o jeito de lidar com esses perigosos é manter um bom relacionamento, tu tens que te dar bem com eles". Sabem que, com raiva e ódio, quem praticou um homicídio pode repetir a ação. Assim que, a estratégia consiste em manter-se em harmonia com ela.

Esta medida de precaução é justificada por alguns com a argumentação de que não é em todas as situações que quem personifica socialmente a posição de criminoso se manifesta como tal. Em outras palavras, pessoas com um histórico de vida criminosa, nem sempre têm um comportamento desviante; apesar de terem incorrido em crimes, não são criminosas em todos os planos da vida. Em algumas ocasiões, elas assumem papéis sociais fora da esfera do crime, seguem as normas conforme as regras da sociedade. Esta ambivalência na figura social do criminoso desperta, em quem o conhece, posições ambíguas.

A respeito desta ambigüidade é elucidativa a fala de uma senhora que aluga peças em sua casa, dizendo que, quando conversa com uma pessoa faz isso sem conhecer seus antecedentes, pois, 
“(...) não está escrito na testa 'eu sou ladrão'. 0 bandido, o drogado, para te tratar são umas maravilhas. Eu já botei dentro de minha casa um, chegou pedindo comida, era ex-presidiário, fugitivo. Falou: 'tia obrigada'. O utra vez aluguei uma peça para um drogado, não era mais de maconha, era de craque. Maconha é o começo e o craque é o fim. Descobri que era viciado em craque depois de cinco meses que saiu de minha casa, quando achei um cachimbo. Ele me tratava maravilhosamente bem, tia para lá e tia para cá, pagava direitinho".

O clima generalizado de insegurança que emana do mundo imprevisível torna impossível a emissão de juízos confiantes, de maneira que solapa o comportamento desviante. Mas quando o desviante se torna normal, toda normalidade é suspeita de desvio. 0 crime hoje não é mais estigmatizado como a ruptura da norma, mas como ameaça à segurança (BAU M AN, 2000)

Vale a pena salientar que não são unicamente as relações com os criminosos conhecidos que geram constrangimento, mas também a relação com desconhecidos. 0 desconhecido é temido, pela impossibilidade com que as pessoas se deparam de exercer um controle sobre ele, a vulnerabilidade ao outro. Em encontros com desconhecidos, as pessoas não duvidam em expressar uma ruptura radical com outro, negando-Ihe a fala. Se este tenta estabelecer uma comunicação, por mais efêmera que seja (pedir informações de ruas) Ihe é negada. Esta é a atitude verbalizada por adultos diante do desconhecido, e eles costumam transmiti-la aos fiIhos. U ma das regras de comportamento imbuídas no processo de socialização é não receber nada de desconhecidos, postura que se resume à desconfiança, indicadora do esvaziamento do sentimento coletivo, mencionado anteriormente, que caracteriza a sociabilidade em cidades dominadas pela violência. Nelas, as únicas comunidades possíveis de serem construídas pelos solitários são as do medo, a suspeita e o ódio (BAU M AN, 2000). 
No meio da inconsistência e fragilidade da solidariedade nas comunidades contemporâneas, as durezas e sofrimentos são fragmentados e dispersos. A dificuldade de condensá-los numa causa comum se torna uma das dores amargas. A vida é saturada de sombrias apreensões e sinistras premonições, assustadoras por sua não especificidade, por seus contornos imprecisos (BAU MAN, 2000). O s indivíduos, nem sós, nem acompanhados, podem combater as ameaças à segurança de sua condição social ou à certeza sobre perspectivas futuras. Q uadro que ajuda a compreender em que sentido o medo à vitimização dos jovens, derivado da alta vulnerabilidade à violência a que eles estão expostos em ambientes sociais como os de Alvorada e São Leopoldo, afeta o desenvolvimento de projetos de vida individuais ou coletivos de uma ampla parcela de pessoas dessa geração.

\section{Controle social institucional}

A polícia, a Igreja e a família representam instituições que evocam e defendem princípios morais e visam controlar e prevenir ações voltadas para o crime (RASERA, 2008). De acordo com a situação, estas instituições punem ou protegem pessoas que infringem esses princípios e adotam um comportamento desviante, voltado para o crime. Não há unanimidade, em cada uma das instituições, de como agir. São decisões negociadas, sustentadas em valores morais e regras sociais, específicos para cada instituição.

\section{Família}

Dirigindo a atenção para a família, identificamos algumas atitudes relativas á situação em que um de seus membros pratica um assassinato. U ma delas é mandar embora da casa o algoz, deixá-lo na rua. 0 corre não só por causa de assassinatos, mas também em circunstâncias nas quais as 
famílias são vítimas de crimes de algum de seus membros. Trata-se, por exemplo, de jovens viciados em droga, que pegam dinheiro e objetos do patrimônio familiar e os comercializam para adquirir a droga. Uma outra atitude da família pode ser a ajuda, encaminhando o jovem para atendimento psicológico especializado. E a terceira atitude conhecida é entregálo à polícia, geralmente com a intenção de protegê-lo das ameaças de morte por vingança, porém às vezes é uma forma de punição familiar.

As famílias de assassinos têm medo de vingança, pois esta é uma prática cultural arraigada, executada por familiares próximos da vítima (geralmente os irmãos ou primos). Trata-se da vingança de sangue, destinada à preservação da honra da família. Contudo, a honra da família, em alguns casos, não é defendida com a morte dos assassinos do parente, isso ocorre, segundo as falas, "quando o cara não é grande coisa, a família não cobra com vingança" (RASERA, 2008).

Igreja

Q uanto à posição das Igrejas, algumas pessoas, como porta-vozes das Igrejas, argumentam que a salvação está em D eus. Por ser D eus quem tem o poder de mudar às pessoas e de ajudar a melhorar a vida, de proteger contra a morte violenta. 0 s seguidores das Igrejas Evangélicas acreditam na possibilidade de recuperação das pessoas, "mesmo atrás das grades". Elas descrevem situações em que as pessoas largam a droga, e com a intervenção de uma Igreja, incorporam-se à sociedade, apesar das dificuldades que este processo implica. Ao mesmo tempo, as Igrejas preconizam valores e regras determinantes para o seguimento de um bom comportamento. 0 discurso religioso oscila entre o bem e o mal. Sendo o bom comportamento: trabalhar, estudar, ter a casa, ter filhos. Isto é, contribui para a reprodução da família. 
No âmbito da Igreja, os fiéis qualificam o envolvimento com drogas, de doença e, diante dele, quem tem o poder de cura é Deus. Consideram que os envolvidos em tráfico e consumo de drogas devem procurar as Igrejas, em busca da ajuda que estas oferecem. Então, se por um lado, as Igrejas Evangélicas assumem a função de ajudar as pessoas que tenham algum envolvimento com o negócio das drogas e outras formas de criminalidade, por outro, a Igreja Católica dá conselhos e encaminha as pessoas nessas situações para entidades assistenciais especializadas em tratamentos para esses problemas.

No entanto, se há os que acreditam no poder de recuperação das Igrejas, há os céticos em relação ao poder das Igrejas. Desde esta última posição, colocou-se uma mulher que disse conhecer situações em que "a pessoa, depois de sair da Igreja, volta com tudo de novo, parece que aquilo não foi nada".

\section{Polícia}

A quebra da funcionalidade do controle social exercido pela família e pela Igreja não tem sido substituída pela polícia, em vista de que, no contexto histórico e social no qual se ambientam estas reflexões, a polícia tem sua imagem corroída. A desmoralização da instituição e a descrença nos profissionais são amplamente destacados socialmente. Percepções construídas, em parte, em decorrência da desmedida utilização da violência como forma de controle social da polícia. Os excessos ao aplicar o poder de usar a força e a arbitrariedade nas ações foram argumentos recorrentes nas narrativas para desqualificá-la, salientando sua ineficiência no exercício de suas funções. Os dados empíricos produzidos pela pesquisa indicam que ambas as gerações de pessoas entrevistadas opinam que a polícia deveria "trabalhar direitinho", mas em diversas ocasiões não o faz: "M uitas vezes a polícia tira a vida das pessoas". 
A polícia tem perdido legitimidade pela orientação seletiva assumida nos processos e por suas práticas de desvio às normas. U m amplo número de polícias envolve-se em ações de violência, corrupção, tortura e grupos de extermínio e age indiferente aos valores humanistas acabando por produzir a impotência da segurança pública no controle da criminalidade. A polícia, como detentora do poder de exercer a violência e em nome do combate ao crime, comete bastantes arbitrariedades.

Acerca da arbitrariedade da polícia em suas ações, tivemos conhecimento no relato de casos nos quais a polícia não prende os protagonistas de crimes, principalmente homicídios, mesmo que perante a legislação nacional e a instituição que ela representa isso seja sua obrigação. 0 comportamento da polícia é sustentado em regras sociais e valores culturais amplamente difundidos, segundo os quais, é legítimo matar alguém quando é em defesa própria. Igualmente, quando a vítima é qualificada socialmente de bandido, pois tem "ficha na polícia", a atitude da polícia consiste em eximir o algoz da punição, deixá-lo em liberdade. Postura através da qual valida e dissemina a prática social da "justiça pelas próprias mãos", do linchamento.

A análise dessa posição da polícia corresponde às observações feitas por M ichaud (1982), “o trabalho da polícia não está necessariamente de acordo com os processos formais de legalidade. 0 objetivo da polícia é a aplicação eficiente de certas leis e regras, bem como a manutenção da ordem, muito mais do que o respeito integral da legalidade" (p.98). Nestas circunstâncias, percebemos a importância em considerar as normas culturais nos processos de socialização, bem distantes das normas da sociedade global. Fenômeno elucidativo no exame da vitimização dos jovens.

A violência policial afeta imensamente a vida dos jovens, por causa disso, debruçamo-nos na análise do conteúdo semântico dos relatos da ação policial e suas práticas violentas contra jovens (não houve alusão à violência policial exercida contra outras gerações). Com o propósito de esmiuçar os valores simbólicos que dão sustento às práticas de violência poli- 
cial contra os jovens, estimulamos as pessoas entrevistadas a relatarem acontecimentos evocados pela memória coletiva. Através da narrativa de fatos violentos, apreendemos as representações sobre a violência policial quando os jovens foram vítimas. Além disso, como a verdade de um fenômeno social é definida pelo significado que os sujeitos - na posição de sujeitos sociais - dão a eventos e atos, incluímos na análise a violência simbólica que, ao ser descoberta, abre caminho para expressar os sentimentos ocultos dos sujeitos e aumentar o grau de conscientização do problema.

0 quadro apresentado sobre violência da polícia nos remete à questão dos direitos humanos: à sua violação por parte dos policiais no exercício de suas funções, atingindo principalmente o setor jovem da população. 0 mapeamento dos discursos revela que, no âmbito do contexto social examinado, a polícia desrespeita os direitos humanos, ao invés de se constituir em promotora ativa dos mesmos, que é o esperado (SO ARES, 2003). Essa interpretação do fenômeno, consensual, está voltada para a descrição de um conflito social.

U m paradoxo apontado pela pesquisa foi que, apesar de ocuparem posições diferentes, vítima e algoz partilham do mesmo universo de valores culturais. Em nossas reflexões, confirmamosa argumentação de Soares (1996), segundo a qual, no plano moral, há uma fusão entre agressor e vítima, a vítima atingida, ameaçada e humilhada vive, no momento da agressão ou depois, sentimentos de ódio, de vingança sobre o algoz. Ambos, vítima e agressor igualam-se na disposição para a violência. É o que indicam os relatos da participação de policiais em atos violentos. D este modo, em brigas entre gangues, os policiais entram nos confrontos agindo da mesma forma e com as mesmas regras que as gangues. No final, matam-se entre si. O utro fato que demonstra que os dois atores (polícia e jovem) partilham de valores semelhantes e que, se como vimos antes, os jovens carentes de recursos para obter bens de consumo cometem crimes, os policiais agem de igual maneira. Eles pegam dinheiro dos adolescentes, obrigam-nos a 
Ihes dar dinheiro para comprar lanche e pagar as passagens. Também se equiparam em valores e práticas ao atuarem nas cadeias como vendedores de drogas.

Por outra parte, a polícia assemelha-se culturalmente às gangues e narcotraficantes no uso da violência como instrumento de poder. Q uanto à ação da polícia com violência, postulamos, com base nas teorias de Arendt (1994), que esta é uma estratégia utilizada para responder à falta de poder social e à perda de legitimidade institucional que ela detém. Quer dizer, diante das perdas, a polícia responde com o poder da violência ${ }^{11}$. Processo acirrado ainda mais pelo crescimento paralelo do poder de outros atores sociais como gangues e traficantes.

A oposição entre estes atores sociais (polícia e jovens) é acentuada em situações em que a polícia, valendo-se do poder institucional de coerção e de uso da força, desenvolve práticas de corrupção e desrespeito em relação aos jovens. A esse respeito, foram diversas as situações empíricas relatadas. Para elucidar a questão, citamos algumas delas: os policiais colocam os jovens no paredão, requisitando-os, chamando-os de fedorentos. Fazem batidas, principalmente nos finais de semana, em lanchonetes, restaurantes e outros locais públicos e agridem os adolescentes. "Sabem quem é bom e quem é ruim e partem para o irrespeito", afirma a mãe de adolescentes que presenciam freqüentemente essas situações.

O sjovens, independentemente do tipo de ação praticada, são tratados pela polícia de "bandidos". Ao circular de moto, a polícia pára os jovens e os maltrata. Nos espaços públicos, estabelecimentos e ruas, os policiais os agridem e prendem, apesar de eles não terem dado nenhum motivo, foi o que disseram as pessoas ao se manifestarem sobre o assunto. N os discursos, fazem a ressalva de que o tratamento de bandidos é mais evidente

11 Arendt (1994) observa que a ineficiência policial, nos Estados U nidose na Europa, é acompanhada da violência policial. 
quando os jovens, pela aparência física, são categorizados de negrose pobres. Sobre 0 assunto, a coordenadora de um grupo de assistência a jovens narra a situação que presenciou: nela, os jovens, participantes do programa, foram barrados e maltratados, sem causa, pela polícia. Referindo-se à atuação da polícia, ela afirma: "partem com violência para cima da gurizada, sendo guris bons, dão soco e batem com cacete". Ação justificada pela polícia como uma forma de exercer o controle sobre o porte e o consumo de drogas.

$N$ ão identificamos diferenças entre as duas gerações no conteúdo dos discursos quando o assunto é a atuação policial. No âmbito da geração de adultos, perpassa uma critica negativa ao trabalho policial, consideram-no lento, pois a polícia não age com a rapidez em que ocorrem os acontecimentos: quando é procurada, não acode oportunamente. "Se acontece algo, a pessoa chama a polícia e, quando ela chega, é tarde demais", afirmam. Além disso, a polícia não oferece segurança, pois não está presente nos espaços públicos na quantidade necessária para evitar roubos. Acham que o contingente policial não é suficiente para impedir que eles, autodesignados de "velhos", sejam alvo de roubos. U ma das informantes destaca que os velhos, por sua condição, precisam de maior proteção que osjovens.

As colocações dos jovens em relação ao trabalho policial coincidem com as idéias apresentadas pelos adultos relativamente à ausência da polícia no momento dos acontecimentos. Ponderam que, em múltiplas ocorrências de crime, "a polícia não dá nem sinal de vida". Consideram que se a polícia estivesse mais presente nas ruas não haveria tanta morte. Reclamam também da impunidade, afirmam que, quando acontecem homicídios, a polícia não faz nada. As pessoas são assaltadas na rua e mortas por falta da vigilância policial que previna estas ocorrências. Em conseqüência disso, os jovens são induzidos a carregar armas para se defenderem da violência e praticarem a justiça que a polícia não exerce. Salientam que esta última só está presente em situações de violência ligadas ao narcotráfico. 
Sugerem com essa afirmação, uma hierarquização das ações policiais, que priorize o combate ao narcotráfico.

Paradoxalmente, os jovens, em seus discursos, legitimam a violência policial contra pessoas de sua mesma geração, no caso de a violência constituir-se em ação punitiva contra alguém que tenha incorrido em crime. Desta ótica, os delinqüentes devem ser perseguidos com toda a força da lei, e o culpável sempre procura ser castigado. A interpretação dessa postura sob inspiração nas teorias Garland (2005), revela que, apesar da proposta do Estado de bem-estar social em arquivar as medidas punitivas, pelas práticas policiais percebemos que os sentimentos punitivos desaparecem unicamente do discurso oficial, pois continuam presentes na cultura popular e no senso comum. As apreciações do senso comum fundamentam-se em considerações e ideologias que demandam a qualquer custo justiça, castigo e proteção.

Ao todo, foram poucas as colocações em defesa da violência policial ${ }^{12}$. Em termos gerais, sobressaem as ambigüidades e contradições inerentes às posições sociais relativas à questão. E para compreendê-las, finalizamos este artigo remetendo-nos à interpretação feita pela Academia. N essa perspectiva, o recurso à violência por parte da polícia para exercer o controle social é uma característica de sociedades estratificadas, no âmbito das quais, o crime e os comportamentos marginais são salientados pelas autoridades públicas para legitimar a aplicação de políticas sociais que afetam as camadas baixas da população e justificar o desenvolvimento de um Estado disciplinar. Nesse marco, o crime é atribuído à falta de disciplina, de autocontrole e controle social. Portanto, para ser resolvido é necessário impor um controle maior e marginalizar os sujeitos qualificados de perigosos.

12 Q uanto ao papel da polícia, houve escassos depoimentos, mesmo porque os informantes não foram instigados a falar no assunto. No entanto, registramos algumas posições em sua defesa. N elas, destacaram que implica em risco de vida permanente e a remuneração não corresponde com a magnitude do trabalho realizado. Isto é, ponderam que um profissional que exponha sua vida para defender a outro e ao que é de outro deve ter uma boa remuneração, o qual, desse ponto de vista, não sucede com os policiais dos municípios. Postulamos que esta última colocação é um outro indicativo da proximidade social que existe entre policiaise cidadãos comuns (jovense adultos) em alguns âmbitos da vida social. 


\title{
Social control expressed in social representations of violence, insecurity and fear.
}

\begin{abstract}
The article argues ways of institutional functioning of the Women's Police Stations and the Criminal Special Courts in the attendance to the cases of domestic violence, before the Maria da Penha Law, taking as counterpoint the presentation of an experience developed in one Women's Police Station of Sergipe State, in which was implanted, during two years, in experimental character, a Nucleus of Mediation of Conflicts. The work argues the social function of the Police and of Justice, for beyond the repression to crime, debating, on a hand, the limits of the penal actions, and on the other hand, the application of the legal instrument of mediation of conflicts in police spaces, faced to the confrontation of the violence against the woman. Finally, it makes some appreciations on the new Brazilian legislation for the attendance to the women in situation of domestic violence.
\end{abstract}

Keywords: Women's Police stations. Domestic violence. Mediation of conflicts.

\section{Referencias}

ARANTES, José Tadeu. A indústria do medo. Le Monde diplomatique, Brasil. Ano 1 No. 2, setembro de 2007.

AREN DT, H annah. Sobre a Violência. Rio de Janeiro: Relume-D umará, 1994.

BAU M AM, Zigmunt. Em Busca da Política. Rio de Janeiro: Jorge Zahar, 2000.

BECK, Ulrich. Incertezas fabricadas. Em Sociedade do risco. O medo na contemporaneidade. IHU O NLINE- Unisinos. São Leopoldo, maio, 2006.

BERM AN, M arshall. Tudo que é sólido desmancha no ar: aventura da modernidade. São Paulo, Companhia das letras, 1986.

BIRM AN, Joel. Mal-estar na atualidade: a psicanálise e as novas formas de subjetivação. 5ạ. Ediçãa. Rj. Civilização Brasileira, 2005.

BO U RDIEU, Pierre. 0 O fício de sociólogo: metodologia da pesquisa na sociologia/ Pierre Bourdieu, Jean Claude Chamboredon; Jean Claude Passeron; tradução Guilherme Joan Freitas Teixeira- Petrópolis, Rj; Vozes, 2004. $\overline{1997 .}$

. Sobre a televisão. Trad. Maria Lúcia Machado. Rio de Janeiro, Jorge Zahar, 
CASTRO, Mary Garcia e ABRAM O VAY, M iriam. Jovens em situação de pobreza, vulnerabilidades sociais e violências. Cad. Pesqui. n.116 São Paulo jul. 2002 DEBERT, G.G. A Reinvenção da Velhice. São Paulo, ESDUSP. Fapesp, 1999.

DELUM EAU, J. História do medo no ocidente: 1300-1800, uma cidade sitiada. São Paulo: Companhia das Letras, 1989.

ECKERT, Cornélia. A cultura do medo e tensões do viver a cidade: narrativa e trajetória de velhos moradores de Porto Alegre. In: Antropologoia, Saúde e enveIhecimento. O rgs. M aria ceclia de Souza M inayo e Carlos E.A. Coimbra. RJ. Editora FIOCRUZ, 2002.

FOU CAULT, M ichel. Vigiar e Punir: nascimento da prisão: tradução de Raquel Ramalhete, Petrópolis, Vozes, 1987.

GARLAND, David. La Cultura del Control: crimen y orden social em la sociedad contemporânea (Traducción: Máximo Sozzo). 1àedición, Editorial Gedisa, S.A. Barcelona, España, 2005.

GID DENS, Anthony. As conseqüências da modernidade. 1. ed. São Paulo: UNESP, 1991.

HELLER, Agnes. Teoría de los sentimientos. Mexico: Ediciones Coyoacán, 1999. (Filosoía y Cultura Contemporânea)

H O BBES, Thomas. HO BBES (Coleção Os Pensadores). São Paulo: Nova Cultural, 1999.

MICHAUD, Yves. A violência. São Paulo: Editora Ática, 1982.

NIETZCHE, Friedrich. A geneologia da moral. São Paulo. Editora Escala, 2a. Edição. 2007.

NO VAES, Regina; VANNU CHI, Paulo. Juventude e Sociedade: trabalho, educação, cultura e participação. São Paulo: Fundação Perseu Abramo, 2004.

O LIVEIRA, Roberto Cardoso se. Razão e afetividade: o panorama de Lucien LevyBrruhl. Campinas, U nicamp. 1991. Coleção CLE, v.8

RASERA, Anapaula. Representações Sociais de Violência: (in)segurança, medo e vulnerabilidades; Estigmas de Alvorada, RS. Dissertação de M estrado. Universidade do Vale do Rio dos Sinos. Programa de Pós-Graduação em Ciências Sociais Aplicadas. São Leopoldo, BR-RS, 2008.

RIELLA, Alberto. Violencia y control social: el debilitamento del orden social moderno. Porto Alegre. PPGS/U FRGS. Revista Sociologias, ano 1, No. 1. 1999, pp: 122-145. 
RO LIM, Marcos. Projeto paz urbana. Plano de Segurança Pública de Alvorada, reduzindo o crime, a violência e o medo. Trabalho de Consultoria, outubro de 2004.

SEN NETT, Richard. A Cultura do Novo Capitalismo. São Paulo: Record, 2006. SO ARES, Luis Eduardo. Prefácio. In: Direitos Humanos: coisa de policia, (org) BALESTRERI, R.B. 3åEdição, editora CAPEC, Passo Fundo (RS) 2003). $\overline{1996 .}$

. Violência e política no Rio de Janeiro. Rio de Janeiro, Relume Dumará: ISER, SO NTAG, Susan. Diante da dor dos outros. Companhia das Letras, São Paulo, 2003.

TAVARES dos Santos, José Vicente. Violências, América latina: a disseminação de formas de violência e os estudos sobre conflitualidades". Revista SO CIO LO GIAS, Porto Alegre, PPG- Sociologia do IFCH-UFRGS, Número 8, novembro de 2002. p: 16-32.

W IEVIO RKA, Michel. Em que mundo viveremos? Trad. Eva Landa e Fabio Landa - São Paulo, Perspectiva, 2006.

YOUNG, Jack. Sociedade Excludente. R.J. Revan. Instituto Carioca de Criminologia, 2002

ZALUAR, Alba. Cultura, educação popular e escola pública. In: Integração Perversa: pobreza e tráfico de drogas/ Alba Zaluar - RJ- Editora FGV, 2004.

Recebido: $16 / 04 / 2008$

Aceite final: 17/06/2008 